\title{
HUBUNGAN PENGETAHUAN DAN SIKAP DENGAN PERILAKU PENCEGAHAN INFEKSI LEPTOSPIROSIS PADA IBU HAMIL
}

\author{
Intan Nugraheni Hasanah ${ }^{1)}$, Sri Wahyuni ${ }^{2)}$ \\ Email : jkaffah@gmail.com
}

\begin{abstract}
Leptospirosis is spread all over the world, on all continents, except the Antarctic continent. Most incidents are found in tropical countries, including Indonesia. According to the International Leptospirosis Society, Indonesia is a country with a high incidence of leptospirosis, and ranks third in the world for mortality.

This study aims to determine the relationship of knowledge and attitude with the prevention behavior of leptospirosis infection in pregnant women. The type of research is explanatory research using cross sectional approach method. Subjects were all pregnant women who were not suffering from leptospirosis infection in Bandarharjo Semarang Public Health Center. Sampling technique using Total Sampling. Univariate analysis of each variable with percentage size. Bivariate analysis using Chi Square statistic.

The result of this research got the knowledge level of pregnant woman to behavior of prevention of leptospirosis infection in Bandarharjo Semarang Public Health Center mostly belong to good category $(70,6 \%)$. The attitude of pregnant mother to behavior of prevention of leptospirosis infection in Bandarharjo Semarang Public Health Center mostly belong to positive category $(58 \%)$. There is correlation between knowledge and attitude with behavior of prevention of leptospirosis infection in pregnant woman in Bandarharjo Semarang Public Health Center area.

This research is expected to motivate people to be more active in finding information about leptospirosis or other health problems.
\end{abstract}

Key words : Knowledge, Attitude, Leptospirosis

${ }_{1,2}$ ) Poltekkes Kemenkes Semarang

Indonesia merupakan negara tropis dengan kejadian leptospirosis yang tinggi. International Leptospi-rosis Sosiety (2001) menyatakan Indo-nesia sebagai negara dengan insiden leptospirosis tinggi dengan peringkat ketiga di dunia dibawah Uruguay dan India untuk mortalitas (Ra-madhani T. dan Yunianto B, 2010: S46). Di Indonesia, leptospirosis ditemukan hampir di seluruh kepulauan. Beberapa provinsi tempat kasus leptospirosis yaitu DKI Jakarta, Jawa Barat, Jawa
Tengah, DI Yogyakarta, Sumatra Selatan, Sumatra Utara, Bali, NTB, Sulawesi Selatan, Sulawesi Utara, Kalimantan Barat, dan Kali-mantan Timur. Pada beberapa peristiwa banjir besar yang menimpa kota-kota besar di Indonesia akhirakhir ini (sekitar tahun 2001-2006), angka kejadian leptospirosis meningkat secara signifikan sehingga menjadi bahan pemberitaan di media massa. Hal tersebut relatif berbeda dengan tahuntahun sebelum era mile-nium di mana 
leptospirosis kurang dikenal masyarakat. Itulah sebabnya penyakit ini disebut sebagai the re-emerging infectious disease.

Kota Semarang adalah satusatunya daerah di Indonesia yang melaporkan adanya kasus leptospirosis. Insiden leptopsirosis di Kota Semarang 4,59/100.000 dan mortality 17,28\% (Dinkesprov Jateng, 2012: 57).

Secara epidemiologik, kejadian leptopsirosis dipengaruhi oleh 3 faktor pokok, yaitu faktor agent penyakit, seperti jumlah, virulensi, dan patogenitas bakteri leptospira; faktor host (pejamu), seperti kebersihan perorangan, kebiasaan menggunakan alat pelin-dung diri ketika sedang bekerja di tempat berisiko leptospirosis, keadaan gizi, usia, dan tingkat pendidikan; dan faktor lingkungan, seperti lingkungan fisik, kimia, biologik, dan sosial. Leptospirosis merupakan masalah kesehat-an masyarakat di seluruh dunia khu-susnya di negara-negara yang beriklim tropis dan subtropis serta memiliki curah hujan yang tinggi. Tingginya angka prevalensi leptospirosis di daerah yang memiliki iklim tropis dan subtropis, dapat dihubungkan dengan kondisi lingkungan yang kurang baik sehingga memungkinkan lingkungan tersebut menjadi tempat yang baik atau cocok untuk hidup dan berkem-bangbiaknya bakteri leptospira (WHO, 2003).

Leptospirosis berbahaya bagi ibu hamil. Walaupun belum ada keja-dian ibu hamil yang menderita lepto-spirosis yang dilaporkan di Kota Semarang, namun sebagai wanita juga rawan menderita infeksi tersebut. Data profil Kota Semarang tahun 2014 melaporkan bahwa angka kejadian infeksi leptospirosis di Kota Semarang dengan jenis kelamin perempuan sebanyak 24 kasus (32\%) dibanding pria. Bagi ibu hamil penting sekali untuk mengetahui karakteristik infeksi leptospirosis karena infeksi leptospirosis beresiko terhadap kehamilan karena dapat menyebabkan keguguran, bayi lahir cacat dan meninggal, atau lahir prematur.

Upaya penanggulangan yang telah dilakukan oleh Dinas Kesehatan Kota Semarang. Diantaranya bekerjasama dengan Balai Besar Penelitian dan Pengembangan Vektor dan Reservoir Penyakit (B2P2VRP) Salatiga untuk menentukan angka prevalensi sumber penularan. Mengadakan ceramah klinis pada tenaga medis puskesmas, penyuluhan kesehatan di tingkat PKK dan tokoh masyarakat.

Beberapa studi menyebutkan bahwa faktor-faktor yang berhubungan dengan kejadian leptospirosis berat di kota semarang adalah keadaan selokan yang buruk, adanya tikus di dalam/luar rumah, kebiasaan merokok, selang waktu antara timbulnya gejala dengan pemberian terapi antibakteri dan adanya kontak dengan bangkai tikus.

Penting bagi ibu hamil untuk mengetahui perilaku yang tepat dengan tujuan supaya dapat terhindar dari infeksi leptospirosis dan melakukan upaya-upaya pencegahan terutama ibu hamil yang tinggal di wilayah banjir, genangan air / air selokan tidak mengalir, memiliki suami perokok, dan terdapat tikus di dalam maupun luar tempat tinggalnya.

Kecamatan Semarang Utara menduduki peringkat pertama kejadian 
infeksi leptospirosis tahun 2014 (Dinkes Kota Semarang, 2014). Ini disebabkan wilayah Semarang Utara merupakan daerah yang padat penduduknya dengan wilayah yang digenangi air secara terus menerus akibat banjir dan rob dari air laut. Keadaan tersebut menyebabkan adanya perubahan lingkungan seperti : banyaknya genangan air, lingkungan menjadi becek, dan banyak timbunan sampah yang menyebabkan mudahnya kuman leptospira berkembang biak.

Dari latar belakang di atas menjadikan penulis tertarik untuk meneliti hubungan antara pengetahuan dan sikap dengan perilaku pencegahan infeksi leptospirosis pada ibu hamil.

\section{METODE PENELITIAN}

Jenis penelitian ini adalah eksplanatory research dengan menggunakan metode pendekatan cross sectional atau studi potong lintang. Uji validitas dilakukan dengan minimal 25 responden dengan menggunakan Person Correlation Product Moment dan Justifikasi Expert di Puskesmas Karangdoro. Subyek penelitian ini adalah seluruh ibu hamil yang tidak sedang menderita infeksi leptospirosis di Puskesmas Bandarharjo Semarang sebanyak 30 responden. Teknik pengambilan sampel yang dilakukan adalah dengan menggunakan total sampling. Analisis penelitian menggunakan analisis univariat masing-masing variabel dengan ukuran prosentase. Analisis bivariat dilakukan dengan analisis statistik Chi square.
HASIL DAN PEMBAHASAN

\section{Umur Responden}

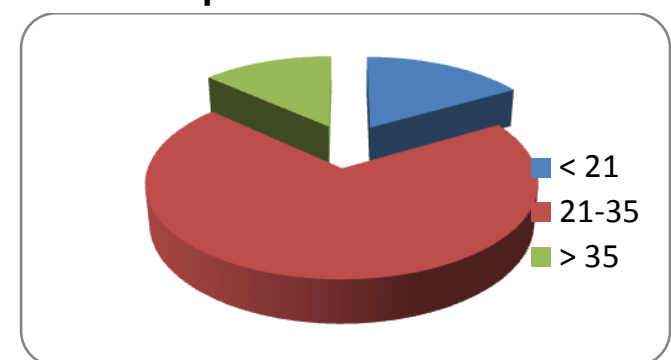

Berdasarkan data diatas didapatkan umur ibu hamil yang menjadi responden dalam penelitian ini rata rata adalah umur 25 tahun dan umur yang muda adalah umur 19 tahun sedangkan untuk umur ibu hamil yang paling tua adalah 36 tahun. Ibu hamil yang menjadi responden dalam penelitian ini memiliki resiko terhadap infeksi leptospirosis yang berakibat pada kesehatan janinnya. Sebagian besar kehamilan ibu dilihat dari umur responden dalam rentang reproduksi sehat yaitu usia 20-35 tahun (21 orang), artinya ibu hamil yang menjadi responden masih dalam rentang umur yang baik untuk proses reproduksi.

Daya tangkap dan pola pikir seseorang terhadap suatu objek akan meningkat seiring dengan bertambahnya usia sehingga pengetahuan yang diperolehnya semakin membaik (Notoatmodjo, 2012). Bertambahnya informasi tentang suatu objek menjadikan salah satu hal yang dapat membentuk sikap seseorang (Azwar, 2011). Pada dasarnya leptospirosis dapat menyerang pada semua kelompok umur (Isselbacher dkk, 2012).

\section{Pengetahuan Responden}




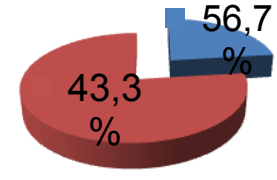

Pada uji statistik Chi Square didapatkan $p$ value $<0,03$ ( $p$ value $<$ 0,05 ) sehingga dapat disimpulkan bahwa ada hubungan antara pengetahuan ibu hamil dengan perilaku pencegahan leptospirosis pada ibu hamil.

Pengetahuan yang rendah tentang leptospirosis mengakibatkan masyarakat kurang memahami tentang penularan leptospirosis, tanda dan gejala, serta pencegahan penyakit untuk memperkecil resiko terkena leptospirosis.

Pada pengisian kuesioner pengetahuan, sebanyak 19 responden salah dalam menjawab soal pada indikator dampak penyakit lepto bagi ibu hamil adalah keguguran, prematur, bayi lahir cacat dan lahir mati. Pengetahuan masyarakat tentang leptospirosis dapat dipengaruhi oleh banyak faktor. Salah satunya ialah informasi dari media cetak maupun media elektronik. Budiman \& Riyanto (2013) mengatakan bahwa adanya informasi baru mengenai suatu hal memberikan landasan kognitif baru bagi terbentuknya pengetahuan terhadap hal tersebut. Hal ini sesuai dengan teori L. Green yang menyatakan bahwa perilaku seseorang tentang kesehatan tidak hanya dipengaruhi oleh pengetahuan seseorang akan tetapi ada faktor lain yaitu kepercayaan, keyakinan, budaya, tradisi dan sebagainya.
Dari hasil penelitian ini bahwa pengetahuan masyarakat dapat dipengaruhi oleh beberapa faktor, dimana faktor-faktor tersebut dapat menjadikan masyarakat berpengetahuan baik atau berpengetahuan kurang tergantung dari bagaimana masyarakat tersebut menyikapi dengan akal budinya untuk mengenal sesuatu yang belum pernah mereka lihat sebelumnya. Pengetahuan seseorang tentang kesehatan merupakan salah satu aspek penting sebelum terjadinya perilaku kesehatan.

\section{Sikap Ibu Hamil}

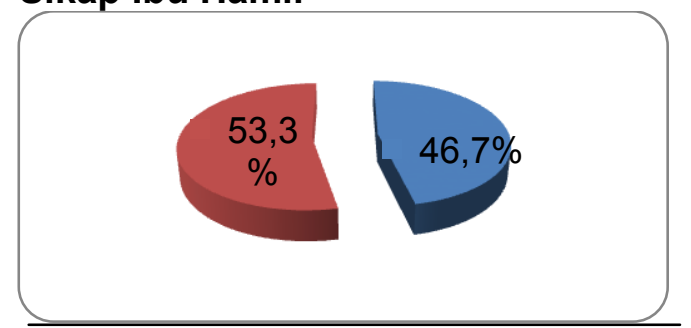

Berdasarkan data diatas didapatkan sebagian besar ibu hamil mempunyai sikap mendukung terhadap perilaku pencegahan leptospirosis yaitu sebanyak 16 orang $(53,3 \%)$. Sebagian besar responden memiliki sikap mendukung dan aktif terhadap perilaku pencegahan leptospirosis sebesar 58 $\%$.

Sikap merupakan suatu bentuk kesiapan atau kesediaan untuk bertindak, dan bukan merupakan pelaksanaan motif tertentu (Newcomb dalam Notoatmodjo, 2010). Output sikap pada setiap individu dapat berbeda, jika suka atau setuju terhadap suatu objek maka akan mendekat, mencari tahu, dan bergabung, sebaliknya jika tidak suka atau tidak setuju maka akan 
menghindar atau menjauhi (Budiman \& Riyanto, 2013).

Azwar (2011) menyatakan bahwa terdapat beberapa faktor yang mempengaruhi pembentukan sikap seseorang, antara lain pengalaman pribadi, pengaruh orang lain, kebudayaan, media massa dan faktor

\begin{tabular}{lcccccc}
\hline & \multicolumn{3}{c}{$\begin{array}{l}\text { Perilaku Pencegahan } \\
\text { Leptospirosis }\end{array}$} & \multicolumn{2}{c}{ Total } \\
\cline { 2 - 6 } Peng & \multicolumn{2}{c}{$\begin{array}{c}\text { Kurang } \\
\text { aktif }\end{array}$} & \multicolumn{2}{c}{ Aktif } & & \\
& f & $\%$ & $\mathrm{f}$ & $\%$ & $\mathrm{f}$ & $\%$ \\
\hline Cukup & 9 & 69,2 & 4 & 30,8 & 13 & 10 \\
& & & & & & 0 \\
\hline Baik & 5 & 29,4 & 12 & 70,6 & 17 & 10 \\
& & & & & & 0
\end{tabular}

emosional.

Berdasarkan beberapa hal tersebut, sikap masyarakat dalam mencegah leptospirosis tergantung pada faktor yang mempengaruhi terhadap sikap masyarakat tersebut. Apabila faktor yang mempengaruhi cenderung positif maka masyarakat juga akan memiliki sikap yang positif, namun sebaliknya apabila faktor tersebut cenderung negatif, maka masyarakat akan memiliki sikap negatif pula Sikap merupakan suatu bentuk kesiapan atau kesediaan untuk bertindak, dan bukan merupakan pelaksanaan motif tertentu (Newcomb dalam Notoatmodjo, 2012).

Sikap ibu hamil dalam mencegah leptospirosis sebanyak $58 \%$ responden memiliki sikap yang positif, terlihat dari sebagian responden yang menjawab soal dengan baik. Hal ini dapat disebabkan oleh beberapa faktor diantaranya pengalaman pribadi seseorang yang pernah terkena leptospirosis atau keluarga yang anggota keluarganya pernah terkena leptospirosis sehingga mengambil sikap yang baik dalam mencegah leptospirosis. Selain itu, faktor yang dapat mempengaruhi sikap masyarakat adalah pengaruh orang lain yaitu ketika seseorang memiliki sikap negatif, orang tersebut dapat memiliki sikap positif ketika terpengaruh oleh orang lain yang memilki sikap positif dalam mencegah leptospirosis.

\section{Hubungan Pengetahuan Ibu Hamil Dengan Perilaku Pencegahan Leptospirosis pada Ibu Hamil}

Pada uji statistik Chi Square didapatkan $p$ value $<0,03$ ( $p$ value $<$ 0,05 ) sehingga dapat disimpulkan bahwa ada hubungan antara pengetahuan ibu hamil dengan perilaku pencegahan leptospirosis pada ibu hamil.

Pengetahuan yang rendah tentang leptospirosis mengakibatkan masyarakat kurang memahami tentang penularan leptospirosis, tanda dan gejala, serta pencegahan penyakit untuk memperkecil resiko terkena leptospirosis. Penelitian yang dilakukan Okatini (2007) menyatakan bahwa orang dengan pengetahuan yang rendah beresiko 17,7 kali terkena leptospirosis dibandingkan dengan orang yang mempunyai pengetahuan tinggi.

Pada pengisian kuesioner pengetahuan, sebanyak 19 responden salah dalam menjawab soal pada indikator dampak penyakit lepto bagi ibu hamil adalah keguguran, prematur, bayi lahir cacat dan lahir mati. Pengetahuan masyarakat tentang leptospirosis dapat dipengaruhi oleh 
banyak faktor. Salah satunya ialah informasi dari media cetak maupun media elektronik. Budiman \& Riyanto (2013) mengatakan bahwa adanya informasi baru mengenai suatu hal memberikan landasan kognitif baru bagi terbentuknya pengetahuan terhadap hal tersebut. Hal ini sesuai dengan teori L. Green yang menyatakan bahwa perilaku seseorang tentang kesehatan tidak hanya dipengaruhi oleh pengetahuan seseorang akan tetapi ada faktor lain yaitu kepercayaan, keyakinan, budaya, tradisi dan sebagainya.

Dari hasil penelitian ini bahwa pengetahuan masyarakat dapat dipengaruhi oleh beberapa faktor, dimana faktor-faktor tersebut dapat menjadikan suatu masyarakat berpengetahuan baik atau berpengetahuan kurang tergantung dari bagaimana masyarakat tersebut menyikapi dengan akal budinya untuk mengenal sesuatu yang belum pernah mereka lihat sebelumnya. Pengetahuan seseorang tentang kesehatan merupakan salah satu aspek penting sebelum terjadinya perilaku kesehatan.

Hubungan Sikap Ibu Hamil Dengan Perilaku Pencegahan Leptospirosis pada Ibu Hamil

Tabel Tabulasi Silang Sikap Dengan Perilaku Pencegahan Leptospirosis

\begin{tabular}{lllllll}
\hline \multirow{2}{*}{ Sikap } & \multicolumn{2}{l}{$\begin{array}{l}\text { Perilaku Pencegahan } \\
\text { Leptospirosis }\end{array}$} & \multicolumn{2}{l}{ Total } \\
\cline { 2 - 6 } & $\begin{array}{l}\text { Kurang } \\
\text { aktif }\end{array}$ & Aktif & & \\
& F & $\%$ & $\mathrm{~F}$ & $\%$ & $\mathrm{~F}$ & $\%$ \\
\hline Pos & 9 & 42 & 12 & 58 & 21 & 100 \\
\hline Neg & 4 & 44 & 5 & 56 & 9 & 100 \\
\hline
\end{tabular}

Pada uji statistik Chi Square didapatkan $p$ value $<0,01$ ( $p$ value $<$ 0,05 ) sehingga dapat disimpulkan bahwa ada hubungan antara sikap ibu hamil dengan perilaku pencegahan leptospirosis pada ibu hamil.

Sikap merupakan suatu bentuk kesiapan atau kesediaan untuk bertindak, dan bukan merupakan pelaksanaan motif tertentu (Newcomb dalam Notoatmodjo, 2010). Output sikap pada setiap individu dapat berbeda, jika suka atau setuju terhadap suatu objek maka akan mendekat, mencari tahu, dan bergabung, sebaliknya jika tidak suka atau tidak setuju maka akan menghindar atau menjauhi (Budiman \& Riyanto, 2013).

Azwar (2011) menyatakan bahwa terdapat beberapa faktor yang mempengaruhi pembentukan sikap seseorang, antara lain pengalaman pribadi, pengaruh orang lain, kebudayaan, media massa dan faktor emosional. Hal ini dapat disebabkan oleh beberapa faktor diantaranya

Berdasarkan beberapa hal tersebut, sikap masyarakat dalam mencegah leptospirosis tergantung pada faktor yang mempengaruhi terhadap sikap masyarakat tersebut. Apabila faktor yang mempengaruhi cenderung positif maka masyarakat juga akan memiliki sikap yang positif, namun sebaliknya apabila faktor tersebut cenderung negatif, maka masyarakat akan memiliki sikap negatif pula Sikap merupakan suatu bentuk kesiapan atau kesediaan untuk bertindak, dan bukan merupakan pelaksanaan motif tertentu (Newcomb dalam Notoatmodjo, 2012). 
Sikap ibu hamil dalam mencegah leptospirosis sebanyak $58 \%$ responden memiliki sikap yang mendukung, terlihat dari sebagian responden yang menjawab soal dengan baik. Hal ini dapat disebabkan oleh beberapa faktor diantaranya pengalaman pribadi seseorang yang pernah terkena leptospirosis atau keluarga yang anggota keluarganya pernah terkena leptospirosis sehingga mengambil sikap yang baik dalam mencegah leptospirosis. Selain itu, faktor yang dapat mempengaruhi sikap masyarakat adalah pengaruh orang lain yaitu ketika seseorang memiliki sikap negatif, orang tersebut dapat memiliki sikap mendukung ketika terpengaruh oleh orang lain yang memilki sikap mendukung dalam mencegah leptospirosis.

\section{SIMPULAN}

Tingkat pengetahuan ibu hamil terhadap perilaku pencegahan infeksi leptospirosis di wilayah Puskesmas Bandarharjo Semarang sebagian besar tergolong dalam kategori baik (70,6\%).

Sikap ibu hamil terhadap perilaku pencegahan infeksi leptospirosis di wilayah Puskesmas Bandarharjo Semarang sebagian besar tergolong dalam kategori mendukung (58\%).

Ada hubungan antara pengetahuan dan sikap dengan perilaku pencegahan infeksi leptospirosis pada ibu hamil di wilayah Puskesmas Bandarharjo Semarang.

\section{SARAN}

Hasil penelitian ini diharapkan dapat memberikan motivasi masyarakat untuk lebih aktif dalam mencari informasi tentang leptospirosis maupun masalah kesehatan lainnya dan bagi tenaga kesehatan agar melakukan penyuluhan kesehatan terkait dengan masalah leptospirosis, sehingga masyarakat mengenal lebih jauh masalah tersebut.

\section{DAFTAR PUSTAKA}

Arikunto, S. 2010. Prosedur penelitian : Suatu Pendekatan Praktik. (Edisi Revisi). Jakarta : Rineka Cipta

Achmadi, Umar Fahmi. 2013. Kesehatan Masyarakat: Teori dan Aplikasi. Jakarta: Raja Grafindo Persada.

Azwar, Saifuddin. 2011. Sikap Manusia: Teori dan Pengukurannya. Yogyakarta : Pustaka Pelajar.

Budiman dan Riyanto, Agus. 2013. Kapita Selekta Kuesioner Pengetahuan dan Sikap Dalam Penelitian Kesehatan. Jakarta: Salemba Medika.

Dinkes Kota Semarang. 2014. Profil Kesehatan Kota Semarang tahun 2014.

Dinkes prov Jateng, 2012. Profil Kesehatan Provinsi Jawa Tengah Tahun 2012. Semarang: Dinkes Prov. Jateng. $\mathrm{h}: 57$

Fitriani, S. 2011. Promosi Kesehatan. Cetakan 1. Yogyakarta: Graha IImu

Mansjoer, 2005 Kapita Selekta Kedokteran edisi 3 Bagian I. Media Aesculapius, FKUI. Jakarta.

Notoatmodjo,S. 2005. Metodologi Penelitian Kesehatan. Jakarta : PT Rineka Cipta 
Notoatmodjo, S. 2012. Promosi Kesehatan dan Perilaku Kesehatan. Penerbit Rineka Cipta. Jakarta.

Notoatmodjo, Soekidjo. 2010. Metodologi Penelitian Kesehatan. Jakarta: Rineka cipta.

Ramadhani T. dan Yunianto B, 2012. Reservoir dan Kasus Leptospirosis di Wilayah Kejadian Luar Biasa. Dalam: Jurnal Kesehatan Masyarakat Nasional Vol. 7, No. 4, November 2012.

Saroso, S. $2003 . \quad P e d o m a n$ Tatalaksana Kasus dan Pemeriksaan Laboratorium Leptospirosis di Rumah Sakit. Jakarta : Departemen Kesehatan R.I.

Swastiko, Priyambodo, 2009. Pengendalian Hama Tikus Terpadu. Cetakan Keempat. Jakarta: Penerbit Swadaya. 20

Wawan, A dan Dewi, M. 2011. Teori dan Pengukuran Pengetahuan, Sikap dan Perilaku Manusia. Yogyakarta : Nuha Medika

WHO, 2003. Human Leptospirosis: Guidance For Diagnosis, Surveillance And Control. International Leptospirosis Society 